\title{
Kurikulum Pendidikan Agama Islam
}

\author{
Nurmadiah, MA
}

\begin{abstract}
Abstrak
Kurikulum merupakan salah satu komponen yang sangat menentukan dalam suatu sistem pendidikan, karena itu kurikulum merupakan alat untuk mencapai tujuan pendidikan dan sekaligus sebagai pedoman dalam pelaksanaan pengajaran pada semua jenis dan tingkat pendidikan. Tujuan pendidikan disuatu bangsa atau negara ditentukan oleh falsafah dan pandangan hidup bangsa atau negara tersebut. Berbedanya falsafah dan pandangan hidup suatu bangsa atau negara menyebabkan berbeda pula tujuan yang hendak dicapai dalam pendidikan tersebut dan sekaligus akan berpengaruh pula terhadap negara tersebut. Begitu pula perubahan politik pemerintahan suatu negara mempengaruhi pula bidang pendidikan, yang sering membawa akibat terjadinya perubahan kurikulum yang berlaku. Dengan demikian kurikulum senantiasa bersifat dinamis guna lebih menyesuaikan dengan berbagai perkembangan yang terjadi. Kurikulum PAI memiliki kedudukan sangat penting untuk membentuk kepribadian seseorang. Dalam kenyataannya, guru PAI sebagai pelaksana kurikulum masih belum memahami hakikat kurikulum. Masih banyak pendidik PAI yang menyusun silabus dan RPP sebagai bagian dari kurikulum hanya untuk administrasi. Dengan memahami kurikulum, para pendidik dapat memilih dan menentukan tujuan pembelajaran, metode, teknik, media pengajaran dan alat evaluasi pengajaran yang sesuai dan tepat. Untuk itu dalam melakukan kajian terhadap keberhasilan sistem pendidikan ditentukan oleh tujuan yang realistis, dapat diterima oleh semua pihak, sarana dan organisasi yang baik, intensitas pekerjaan yang realistis tinggi dan kurikulum yang tepat guna. Oleh karena itu sudah sewajarnya para pendidik dan tenaga kependidikan bidang pendidikan Islam memahami kurikulum serta berusaha mengembangkannya. Komponen kurikulum dalam pendidikan sangat berarti karena merupakan operasionalisasi tujuan yang dicita-citakan, bahwa tujuan tidak akan tercapai tanpa keterlibatan kurikulum pendidikan.
\end{abstract}

Kata kunci: Manajemen, Purikulum, Pendidikan Islam

\section{A. Pendahuluan}

Manusia membutuhkan pendidikan dalam kehidupannya, karena dengan pendidikan manusia dapat mengembangkan potensi diri dan mengembangkan kepribadiannya melalui proses pembelaja- 
ran atau cara lain yang dikenal dan diakui oleh masyarakat. Inti dari kegiatan pendidikan adalah adanya interaksi antara pendidik dengan peserta didik dalam rangka mencapai tujuan pendidikan. Interaksi ini dapat terjadi dalam lingkungan keluarga, sekolah, ataupun masyarakat. Perbedaan yang mendasar antara ketiga model interaksi pendidikan tersebut terletak pada adanya rancangan atau kurikulum formal dan tertulis yang akan disampaikan pada siswa.

Kurikulum mengarahkan segala bentuk aktivitas pendidikan demi tercapainya tujuan-tujuan pendidikan. Kurikulum juga merupakan suatu rencana pendidikan, memberikan pedoman dan pegangan tentang jenis, lingkup, dan urutan isi, serta proses pendidikan. ${ }^{1}$ Dengan demikian, kurikulum memiliki kedudukan penting, baik dalam pendidikan formal maupun non formal karena memberikan arahan terjadinya proses pendidikan.

Kurikulum sebagai rancangan segala kegiatan yang mendukung tercapainya tujuan pendidikan tetap memiliki peran penting, setidaknya dalam mewarnai kepribadian seseorang. Begitupula dengan kurikulum PendidikanAgama Islam (PAI) yang juga memiliki kedudukan yang sangat penting untuk membentuk kepribadian seseorang. Baik dan buruknya hasil pendidikan, termasuk dalam pelaksanaan Pendidikan Agama Islam ditentukan oleh kurikulum, apakah mampu membangun kesadaran kritis terhadap peserta didik atau tidak. ${ }^{2}$ Oleh karena itu, dibutuhkan adanya pemahaman untuk mengimplementasikan kurikulum PAI secara kontekstual agar peserta didik bisa mengaplikasikan dalam kehidupan sehari-hari setelah mendapatkan pembelajaran PAI.

Selama ini, PAI masih dinilai kurang bisa mengubah pengetahuan agama yang kognitif menjadi "makna" dan "nilai" atau kurang mendorong penjiwaan terhadap nilai-nilai keagamaan yang perlu diinternalisasikan dalam diri peserta didik. Dengan kata lain, pendidikan agama selama ini lebih menekankan pada aspek knowing dan doing dan belum banyak mengarah ke aspek being, yakni bagaimana peserta didik menjalani hidup sesuai dengan ajaran dan nilai-nilai

1 Nana Syaodih Sukmadinata,Pengembangan Kurikulum, Teori dan Praktek, (Bandung: Remaja Rosdakarya, 2010), hal. 4.

2 Moh. Yamin, Manajemen Mutu Kurikulum Pendidikan, (Yogyakarta: Diva Press, 2009), hal. 13. 
agama yang diketahui (knowing). ${ }^{3}$ Salah satu faktor yang menyebabkan halter sebut adalah faktor dari guru/pendidik PAI. Seyogyanya pendidik PAI sebagai pelaksana kurikulum PAI harus mampu memahami, mengelola, dan melakukan kegiatan manajemen kurikulum PAI dengan baik. Dengan pemahaman yang baik terhadap kegiatan manajemen kurikulum PAI, pendidik akan dapat memilih strategi, metode, teknik, media, dan alat evaluasi yang sesuai dengan pembelajaran, serta berusaha mengembangkannya sesuai dengan tuntutan perkembangan zaman dan perkembangan kebutuhan masyarakat agar pencapaian tujuan pembelajaran PAI yang lebih menekankan pada aplikasi ajaran agama dalam kehidupan sehari-hari dapat tercapai dengan lancar.

\section{B. Pembahasan}

a. Pengertian Kurikulum

Secara etimologi, kurikulum berasal dari bahasa Yunani yaitu curir yang artinya pelari dan curare yang berarti tempat berpacu. Jadi, istilah kurikilum berasal dari dunia olah raga pada zaman Romawi kuno di Yunani, yang mengandung pengertian suatu jarak yang harus ditempuh oleh pelari dari garis star sampai garis finish. Dalam bahasa Arab, kata kurikulum biasa diungkapkan dengan manhaj yang berarti jalan yang terang yang dilalui oleh manusia pada berbagai bidang kehidupan. Sedangkan kurikulum pendidikan (manhaj al-dirasah) dalam kamus tarbiyah adalah seperangkat perencanaan dan media yang dijadikan acuan oleh lembaga pendidikan dalam mewujudkan tujuan-tujuan pendidikan.

Secara terminologi menurut para ahli mendefinisikan kurikulum diantarnya:

a) Menurut Crow kurikulum adalah rancangan pengajaran atau sejumlah mata pelajaran yang disusun secara sistematis untuk menyelesaikan suatu program untuk memperoleh ijazah.

b) Menurut Arifin kurikulum sebagai seluruh bahan pelajaran yang harus disajikan dalam proses kependidikan dalam suatu sistem institusional pendidikan.

3 Muhaimin, Nuansa Baru Pendidikan Islam; Mengurai Benang Kusut Dunia Pendidikan, (Jakarta: Raja Grafindo Persada, 2006), hal. 123. 


\section{$44 \frac{\text { Jurnal AL-AFKAR }}{\text { Vol. III, No. II, Oktober } 2014}$}

Sesuai dengan perkembangan pendidikan, kurikulum yang semula dipandang sebagai sejumlah mata pelajaran kemudian beralih makna menjadi semua kegiatan atau semua pengalaman belajar yang diberikan kepada peserta didik dalam rangka mencapai tujuan pendidikan dan berada dalam tanggung jawab sekolah, lebih khususnya hasil belajar yang diharapkan. ${ }^{4}$

Dengan demikian pengertian kurikulum dalam pandangan modern merupakan program pendidikan yang disediakan oleh sekolah yang tidak hanya sebatas bidang studi dan kegiatan belajarnya saja, akan tetapi meliputi segala sesuatu yang dapat mempengaruhi perkembangan serta pembentukan pribadi siswa yang sesuai dengan tujuan pendidikan yang akan dicapai sehingga dapat meningkatkan mutu kehidupannya yang pelaksanaannya bukan saja disekolah tetapi juga diluar sekolah. ${ }^{5}$

Dalam Undang-Undang telah dinyatakan:

Kurikulum disusun untuk mewujudkan tujuan pendidikan Nasional dengan memperhatikan tahap perkembangan peserta didik dan kesesuaiannya dengan lingkungan, kebutuhan pembangunan nasional, perkembangan ilmu pengetahuan dan teknologi serta kesenian, sesuai dengan jenis dan jenjang masing-masing satuan pendidikan. ${ }^{6}$

Jadi dapat kita simpulkan bahwa kurikulum merupakan suatu kegiatan pendidikan yang mencakup berbagai rencana kegiatan peserta didik yang terperinci berupa bentuk-bentuk bahan pendidikan, saran-saran strategi belajar mengajar, pengaturan-pengaturan program agar dapat diterapkan, dan halhal yang mencakup pada kegiatan yang bertujuan mencapai tujuan yang diinginkan.

b. Komponen Kurikulum

Mengingat fungsi kurikulum dalam proses pendidikan adalah alat untuk mencapai tujuan pendidikan, maka hal ini berarti sebagai alat pendidikan, kurikulum memiliki bagian-

4 Ramayulis, Ilmu pendidikan Islam,(Jakarta,: kalam Mulia, 1992),hal.150

5 Ibid, hal. 152

6 Oemar Hamalik, Proses Belajar Mengajar, (Jakarta: PT Bumi Aksara, 2001),hal. 66 
bagian penting dan penunjang yang dapat mendukung operasinya dengan baik. Bagian-bagian ini disebut komponen yang saling berkaitan, berinteraksi dalam upaya mencapai tujuan. ${ }^{7}$

Kurikulum suatu sekolah mengandung 3 komponen yaitu:tujuan, isi, dan strategi. Ada 2 jenis tujuan yang terkandung di dalam kurikulum suatu sekolah yaitu :

a) Tujuan kurikulum

1. Tujuan yang ingin dicapai sekolah secara keseluruhan

Selaku lembaga pendidikan, sekolah mempunyai sejumlah tujuan yang ingin dicapainya yang digambarkan dalam bentuk pengetahuan, keterampilan dan sikap yang diharapkan dapat dimiliki siswa setelah mereka menyelesaikan seluruh program pendidikan dari sekolah tersebut.

2. Tujuan yang ingin dicapai dalam setiap bidang studi

Setiap bidang studi dalam kurikulum suatu sekolah juga mempunyai sejumlah tujuan yang ingin dicapainya. Tujuan inipun digambarkan dalam bentuk pengetahuan, keterampilan, dan sikap yang diharapkan dapat dimiliki siswa setelah mempelajari suatu bidang studi pada sekolah tertentu. ${ }^{8}$

b) Isi kurikulum

Berupa materi pembelajaran yang diprogram untuk mencapai tujuan pendidikan yang telah ditetapkan. ${ }^{9}$

c) Media (sarana dan prasarana)

Sebagai sarana perantara dalam pembelajaran untuk menjabarkan kurikulum agar lebih mudah dipahami oleh peserta didik.

d) Strategi

Merujuk pada pendekatan dan metode serta teknik mengajar yang digunakan. ${ }^{10}$

7 Ibid ,hal. 153

8 Muhammad Ali, Pengembangan Kurikulum di Sekolah, (bandung: Sinar Baru, 1992), hal. 52

9 Ibid, hal. 54

10 M. Ahmad, Dkk, Pengembangan Kurikulum, ( Bandung; Pustaka Setia, 1998), 
e) Proses Pembelajaran

Komponen ini sangat penting, sebab diharapkan melalui proses pembelajaran akan terjadi perubahan tingkah pada diri peserta didik sebagai indikator keberhasilan pelaksanaan kurikulum.

f) Evaluasi

Dengan evaluasi (penilaian) dapat diketahui cara pencapaian tujuan. ${ }^{11}$

Menurut Hasan Langgulung ada 4 komponen utama kurikulum yaitu:

a. Tujuan-tujuan yang ingin dicapai oleh pendidikan.

b. Pengetahuan (knowledge), informasi-informasi, data-data, aktivitas, dan pengalaman-pengalaman dari mana terbentuk kurikulum itu.

c. Metode dan cara-cara mengajar yang dipakai oleh guruguru untuk mengajar dan memotivasi murid untuk membawa mereka ke arah yang dikehendaki oleh kurikulum.

d. Metode dan cara penilaian yang dipergunakan dalam mengukur dan menilai kurikulum dan hasil proses pendidikan yang direncanakan kurikulum tersebut.

c. Peran dan Fungsi Kurikulum

a) Kurikulum dipersiapkan dan dikembangkan untuk mencapai tujuan pendidikan, yakni mempersiapkan peserta didik agar mereka dapat hidup di masyarakat. Sebagai salah satu komponen dalam sistem pendidikan, paling tidak kurikulum memiliki tiga peran, yaitu peran konservatif, peran kreatif, serta peran kritis dan evaluatif.

1. Peran Konservatif (melestarikan)

Maksud dari peranan ini adalah melestarikan berbagai nilai budaya sebagai warisan masa lalu. Dikaitkan dengan era globalisasi sebagai akibat kemajuan ilmu pengetahuan dan teknologi, yang memungkinkan mudahnya pengaruh budaya asing masuk dalam budaya lokal. Melalui peran konservatifnya, kurikulum berperan dalam menangkal berbagai pengaruh yang dapat merusak nilai

hal. 106

11 Muhammad Ali, Op. Cit.,hal. 60 
luhur mayarakat.

2. Peran Kreatif

Peran kreatif kurikulum maksudnya dimana kurikulum harus mampu menjawab setiap tantangan sesuai dengan perkembangan dan kebutuhan masyarakat yang cepat berubah. Jadi apabila kurikulum tidak mengandung unsur-unsur baru maka pendidikan selamanya akan tertinggal, yang berarti apa yang akan diberikan di sekolah pada akhirnya akan kurang bermakna, karena tidak relevan lagi dengan kebutuhan dan tuntutan sosial masyarakat.

3. Peran Kritis dan Evaluatif

Kurikulum berperan untuk menyeleksi nilai dan budaya baru yang mana harus dimiliki anak didik. Dalam rangka inilah peran kritis dan evaluatif kurikulum diperlukan. Kurikulum harus berperan dalam menyeleksi dan mengevaluasi segala sesuatu yang dianggap bermanfaat untuk kehidupan anak didik. ${ }^{12}$

b) Fungsi kurikulum adalah sebagai berikut:

a. Alat untuk mencapai tujuan dan untuk menempuh harapan manusia sesuai dengan tujuan yang dicita-citakan.

b. Pedoman dan program harus dilakukan oleh subjek dan objek pendidikan

c. Fungsi kesinambungan untuk persiapan jenjang sekolah berikutnya dan penyiapan tenaga kerja bagi yang tidak melanjutkan

d. Standar dalam penilaian kriteria keberhasilan suatu proses pendidikan, atau sebagai batasan dari program kegiatan yang akan dijalankan pada semester maupun pada tingkat pendidikan tertentu. ${ }^{13}$

d. Kurikulum Pendidikan Agama Islam (PAI)

Kurikulum Pendidikan Agama Islam (PAI) merupakan seperangkat rencana dan pengaturan mengenai tujuan, isi, bahan, serta cara pembelajaran yang digunakan sebagai pedoman penyelenggaraan kegiatan pembelajaran untuk mencapai

12 M. Ahmad, Dkk, Op. Cit., hal. 106

13 Abdul Mujib,dkk, Ilmu Pendidikan Islam, (Jakarta: kencana, 2008), hal.134 
tujuan pendidikan. Ia merupakan sekumpulan studi keislaman yang meliputi al-Qur'an Hadits, Aqidah Akhlaq, Fiqih, Tarikh, dan Kebudayaan Islam. ${ }^{14}$ Sama halnya dengan kurikulum mata pelajaran lain, kurikulum Pendidikan Agama Islam di sekolah juga menjadi acuan dalam kegiatan pembelajaran PAI. Kurikulum PAI dicantumkan dalam kesatuan yang integral bersama-sama dengan bidang studi lainnya dalam satuan kurikulum untuk sekolah. Setiap guru agama sebagai pelaksana kurikulum PAI diharapkan dapat mempelajari dengan sebaik-baiknya dan kemudian dapat menggunakannya sesuai dengan teknik pengajaran berdasarkan prinsip interaktif dan komunikatif dengan memperhatikan kegiatan murid, akan tetapi harus bertindak sebagai pembimbing dan dapat mengkoordinir lingkungan serta menyediakan fasilitas agar anak belajar sendiri. ${ }^{15}$ PAI di sekolah dimaksudkan agar peserta didik berkembang sebagai manusia yang beriman dan bertaqwa kepada Allah SWT, memiliki pengetahuan agama yang luas, dan berakhlaqul karimah. ${ }^{16}$ Untuk itu, dibutuhkan kurikulum PAI yang kontekstual dan dapat melayani harapan masyarakat. Kegiatan pembelajaran PAI dan evaluasi hasil belajar PAI harus dirancang secara kontekstual.

Mata pelajaran PAI masuk pada kelompok mata pelajaran agama dan akhlak mulia dan dimaksudkan untuk membentuk peserta didik menjadi manusia beriman dan bertakwa kepada TuhanYang Maha Esa serta berakhlak mulia, cakupan materinya meliputi etika, budi pekerti, atau moral sebagai perwujudan dari pendidikan agama. ${ }^{17}$ Guna mewujudkan harapan tersebut, kurikulum disusun dengan berpedoman pada SI-SKL, SK-KD, serta panduan penyusunan kurikulum yang disusun oleh Badan Standar Nasional Pendidikan dengan

14 Permendiknas No. 23 Tahun 2006 tentang Standar Kompetensi Lulusan.

15 Rachman Shaleh, Pendidikan Agama Islam Di Sekolah Dasar, (Jakarta: Bulan Bintang, t.t), hal. 12.

16 Rahmat Raharjo, Inovasi Kurikulum Pendidikan Agama Islam, (Yogyakarta: Magnum Pustaka, 2010), hal. 35.

17 E. Mulyasa, Op. Cit., hal. 47. 
mengacu pada prinsip-prinsip pengembangan kurikulum.

Kurikulum PAI yang telah dikembangkan di sekolah selanjutnya dilaksanakan oleh guru PAI pada setiap satuan pendidikan dengan menggunakan prinsip-prinsip pembelajaran yang mendidik. ${ }^{18}$

e. Kerangka Dasar Kurikulum Pendidikan Islam

Kurikulum yang baik dan relevan dalam rangka mencapai tujuan pendidikan Islam adalah yang bersifat intergrated dan komprehensif serta menjadikan al-Qur'an dan hadis sebagai sumber utama dalam penyusunan.

Didalam al-Quran dan hadis ditemukan kerangka dasar yang dapat dijadikan sebagai pedoman operasional dalam penyusunan dan pengembangan kurikulum pendidikan Islam. Kerangka dasar tersebut adalah tauhid dan perintah membaca.

\section{Tauhid}

Tauhid sebagai dasar utama kurikulum harus dimantapkan semenjak masih bayi. Dimulai dengan menperdengarkan kalimat-kalimat tauhid seperti azan atau iqamah terhadap anak yang baru lahir. Tauhid sebagai falsafah dan pandangan hidup umat Islam meliputi konsep ke Maha Esaan Allah, serta ke unikan Allah atas semua makhluknya, Allah SWT, unik dan Esa dalam perbuatan.

Tauhid merupakan prinsip utama dalam seluruh dimensi kehidupan manusia baik hubungan vertikal dengan Allah maupun hubungan horizontal dengan manusia dengan alam. Tauhid seperti inilah yang dapat menyusun pergaulan yang harmonis sesamanya. Kita dapat mewujudkan tata dunia yang harmonis kosmos yang penuh tujuan, persamaan sosial, persamaan kepercayaan, persamaan jenis dan ras, persamaan dalam segala aktivitas dan kebebasan bahkan seluruh masyarakat dunia adalah sama yang disebut "ummatan wahidah".

2. Perintah Membaca

Perintah membaca ayat-ayat Allah meliputi 3 macam yaitu:

18 Rahmat Raharjo, Op. Cit., hal. 36 
1. Ayat Allah yang berdasarkan wahyu

2. Ayat Allah yang ada pada diri manusia, dan

3. Ayat Allah yang terdapat di alam semesta di luar diri manusia.

Firman Allah SWT :
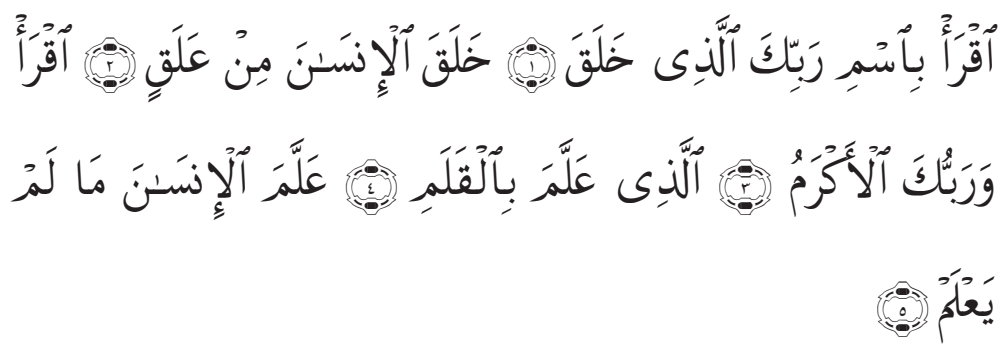

Artinya :

Bacalah! Dengan menyebut nama Tuhanmu yang menciptakan manusia dari segumpal darah. Bacalah! Dan Tuhanmulah yang paling pemurah, yang mengajarkan (manusia) dengan perantaraan kalam, dia mengajar kepada manusia apa yang tidak diketahuinya. (Q.S. 96: 1-5)

Firman Allah SWT itu merupakan bahan pokok pendidikan yang mencakup seluruh ilmu pengetahuan yang dibutuhkan oleh manusia. Membaca selain melibatkan proses mental yang tinggi, pengenalan (cognition), ingatan (memory), pengamatan (perception), pengucapan (verbalization), pemikiran (reasoning), daya cipta (creativity) juga sekaligus merupakan bahan pendidikan itu sendiri.

f. Dasar Kurikulum Pendidikan Islam

Kurikulum sebagai salah satu komponen pendidikan yang sangat berperan dalam mengantarkan pada tujuan pendidikan yang diharapkan, harus mempunyai dasar-dasar yang merupakan kekuatan utama yang mempengaruhi dan membentuk materi kurikulum, susunan dan organisasi kurikulum. Yang menjadi dasar-dasar dalam penyusunan kurikulum pendidikan Islam adalah :

1. Dasar Agama

Seluruh sistem yang ada dalam masyarakat Islam, termasuk sistem pendidikannya harus meletakkan dasar falsafah, tujuan,dan kurikulumnyapada ajaran Islam yang meli- 
puti aqidah, ibadah, muamalat, dan hubungan-hubungan yang berlaku didalam masyarakat. Hal ini bermakna bahwa semua itu pada akhirnya harus mengacu pada dua sumber utama syariat Islam yaitu al-Quran dan Sunnah.

2. Dasar Falsafah

Dasar ini memberikan arah dan tujuan pendidikan Islam, dengan dasar filosofis sehingga susunan kurikulum pendidikan Islam mengandung suatu kebenaran, terutama dari sisi nilai-nilai sebagai pandangan hidup yang diyakini kebenarannya.

3. Dasar Psikologis

Asas ini memberikan bahwa kurikulum pendidikan Islam hendaknya disusun dengan mempertimbangkan tahapan-tahapan pertumbuhan dan perkembangan yang dilalui anak didik. Kurikulum pendidikan Islam harus dirancang sejalan dengan ciri-ciri perkembangan anak didik, tahap kematangan bakat-bakat jasmani, intelektual, bahasa, emosi dan sosial, kebutuhan dan keinginan, minat, kecakapan, dan perbedaan individual antara peserta didik yang satu dengan yang lainnya.

4. Dasar Sosial

Dasar ini memberikan gambaran bagi kurikulum pendidikan Islam yang tercermin pada dasar sosial yang mengandung ciri-ciri masyarakat Islam dan kebudayaannya. Baik segi dari pengetahuan, nilai-nilai ideal, cara berpikir dan adat kebiasaan, serta seni. Sebab tidak ada suatu masyarakat yang tidak berbudaya dan tidak ada suatu kebudayaan yang tidak berada pada masyarakat. Kaitannya dengan kurikulum pendidikan Islam sudah tentu kurikulum ini harus mengakar terhadap masyarakat dan perubahan serta perkembangan.

5. Dasar Organisatoris

Dasar ini memberikan landasan dalam penyusunan bahan pembelajaran beserta penyajiannya dalam proses pembelajaran. ${ }^{19}$

g. Prinsip-Prinsip Penyusunan Kurikulum Pendidikan Islam

Dalam penyusunan kurikulum, kita harus memper-

19 M. Ahmad, Dkk, Op. Cit., Hal. 15 


\section{2

hatikan prinsip-prinsip yang dapat mewarnai kurikulum pendidikan.

1. Prinsip berasaskan Islam termasuk ajaran dan nilainilainya.

2. Prinsip mengarah kepada tujuan adalah seluruh aktivitas dalam kurikulum diarahkan untuk mencapai tujuan yang dirumuskan sebelumnya.

3. Prinsip (integritas) antara mata pelajaran, pengalamanpengalaman, dan aktivitas yang terkandung di dalam kurikulum.

4. Prinsip relevansi adalah adanya kesesuaian pendidikan dengan lingkungan hidup murid.

5. Prinsip fleksibilitas, adalah terdapat ruang gerak yang memberikan sedikit kebebasan dalam bertindak.

6. Prinsip integritas adalah kurikulum tersebut dapat menghasilkan manusia seutuhnya.

7. Prinsip efisiensi, adalah agar kurikulum dapat mendayagunakan waktu, tenaga, dana, dan sumber lain secara cermat dan tepat.

8. Prinsip kontinuitas dan kemitraan adalah bagaimana susunan kurikulum yang terdiri dari bagian yang berkelanjutan dengan kaitan-kaitan kurikulum lainnya.

9. Prinsip individualitas adalah, bagaimana kurikulum memperhatikan perbedaan pembawaan dan lingkungan anak.

10. Prinsip kesamaan memperoleh kesempatan dan demokratis adalah bagaimana kurikulum dapat memberdayakan semua peserta didik memperoleh pengetahuan, keterampilan, dan sikap sangat diutamakan.

11. Prinsip kedinamisan, adalah agar kurikulum itu tidak statis, tetapi dapat mengikuti perkembangan ilmu pengetahuan dan perubahan sosial.

12. Prinsip keseimbangan, adalah bagaimana kurikulum dapat mengembangkan sikap potensi peserta didik secara harmonis.

13. Prinsip efektivitas, adalah agar kurikulum dapat menunjang efektivitas guru yang mengajar dan peserta didik yang belajar. $^{20}$

20 M. Ahmad, Dkk, Op. Cit., hal. 66 


\section{KESIMPULAN}

Kurikulum adalah suatu kegiatan pendidikan yang mencakup berbagai rencana kegiatan peserta didik yang terperinci berupa bentuk-bentuk bahan pendidikan, saran-saran strategi belajar mengajar, pengaturan-pengaturan program agar dapat diterapkan, dan halhal yang mencakup pada kegiatan yang bertujuan mencapai tujuan yang diinginkan. Peran dan fungsi kurikulum terdiri dari: Peranan Konservatif (melestarikan), Peran Kreatif, peran kritis dan evaluatif. Fungsi kurikulum adalah sebagai alat untuk mencapai tujuan dan untuk menempuh harapan manusia sesuai dengan tujuan yang dicita-citakan. Pedoman dan program harus dilakukan oleh subjek dan objek pendidikan, fungsi kesinambungan untuk persiapan jenjang sekolah berikutnya dan penyiapan tenaga kerja bagi yang tidak melanjutkan. Standar dalam penilaian kriteria keberhasilan suatu proses pendidikan, atau sebagai batasan dari program kegiatan yang akan dijalankan pada semester maupun pada tingkat pendidikan tertentu.

Adapun dasar kurikulum pendidikan Islam adalah adanya dasar agama, dasar falsafah, dasar psikologis, dasar sosial, serta dasar organisatoris. Prinsip-Prinsip dalam penyusunan kurikulum, kita harus perhatikan prinsip-prinsip yang dapat mewarnai kurikulum pendidikan, berasaskan Islam termasuk ajaran dan nilai-nilainya. Prinsip mengarah kepada tujuan, Prinsip (integritas), Prinsip relevansi, Prinsip fleksibilitas, Prinsipintegritas, Prinsip efesiensi, dan Prinsip kontinuitas.

\section{Daftar Pustaka}

Abdul Mujib, dkk, Ilmu Pendidikan Islam, Jakarta: kencana, 2008 Drajat, Zaskiah, dkk, Ilmu Pendidikan Islam, Jakarta: Bumi Aksara, 2011

M. Ahmad, Dkk, Pengembangan Kurikulum, Bandung; Pustaka Setia, 1998

Moh. Yamin, Manajemen Mutu Kurikulum Pendidikan, Yogyakarta: Diva Press, 2009 


\section{$54 \frac{\text { Jurnal AL-AFKAR }}{\text { Vol. III, No. II, Oktober } 2014}$}

Muhaimin, Nuansa Baru Pendidikan Islam; Mengurai Benang Kusut

Dunia Pendidikan, Jakarta: Raja Grafindo Persada, 2006

Muhammad Ali, Pengembangan Kurikulum di Sekolah, bandung: Sinar Baru, 1992

Mujid Abdul, dkk, Ilmu Pendidikan Islam, Jakarta:Kencana, 2006

Nana Syaodih Sukmadinata, Pengembangan Kurikulum, Teori dan

Praktek,Bandung: Remaja Rosdakarya, 2010

Oemar Hamalik, Proses Belajar Mengajar, Jakarta: PT Bumi Aksara, 2001

Permendiknas No. 23 Tahun 2006 tentang Standar Kompetensi Lulusan

Rachman Shaleh, Pendidikan Agama Islam Di Sekolah Dasar, Jakarta: Bulan Bintang, t.t.

Rahmat Raharjo, Inovasi Kurikulum Pendidikan Agama Islam, Yogyakarta: Magnum Pustaka, 2010

Ramayulis, Ilmu Pendidikan Islam, Jakarta: Kalam Mulia, 2002

Rasyidin, Al, dkk, Filsafat Pendidikan Islam, Jakarta: Ciputat Press, 2005 